\title{
Immunologic and Virological Profile of Older Adult Patients Infected by the Human Immunodeficiency Virus starting Treatment in Kinshasa, Democratic Republic of Congo
}

\author{
Erick Ntambwe Kamangu* \\ Molecular Biochemistry Service, Département of Basic Sciences, Faculty of Médecine, Université of Kinshasa, DRCongo
}

*Corresponding author: Erick Ntambwe Kamangu, Molecular Biochemistry Service, Département of Basic Sciences, Faculty of Médecine, Université of Kinshasa, DRCongo, Tel: +243 (0) 8154 01; E-mail: erick.kamangu@unikin.ac.cd

Received: 18 Jun, 2018 | Accepted: 12 Dec, 2018 | Published: 19 Dec, 2018

Citation: Kamangu EN (2018) Immunologic and Virological Profile of Older Adult Patients Infected by the Human Immunodeficiency Virus starting Treatment in Kinshasa, Democratic Republic of Congo. J HIV AIDS 4(4): dx.doi.org/10.16966/2380-5536.161

Copyright: (C) 2018 Kamangu EN. This is an open-access article distributed under the terms of the Creative Commons Attribution License, which permits unrestricted use, distribution, and reproduction in any medium, provided the original author and source are credited.

\section{Summary}

Background: Although the National HIV Infection Control Program has adopted the "Test and Treat" option, virological, immunological and clinical parameters are still important for the decision of the appropriate treatment and proper care.

Objective: The objective of this work was to evaluate the immunological and virological profile of HIV-infected patients over 50 years of age starting antiretroviral treatment in Kinshasa.

Methods: Twenty-seven subjects over the age of 50 years diagnosed with HIV Type 1 by serology in 3 treatment centers in Kinshasa during the period from 08 November 2013 to 14 February 2014 participated voluntarily in this work. After signing informed consent, blood samples were collected in $5 \mathrm{ml}$ tubes with EDTA. The CD4 count and Viral Load (VL) were performed in each patient at the inclusion (D0) in the Laboratory of Molecular Biology of the Faculty of Medicine of the University of Kinshasa. The clinical and paraclinical parameters were recorded on the patient files previously designed for the work.

Results: Of the 27 patients, 14 (51.85\%) were women. The median age of the population was 58 years in the range of 50 to 70 years. Four patients (14.8\%) were in clinical stage 2 while $20(74.1 \%)$ in stage 3 and $3(11.1 \%)$ in stage 4 according to the classification recommendations of the World Health Organization. The median CD4 count is 227.78 cells $/ \mathrm{ml}$; the minimum and maximum values were 90 and 350 cells $/ \mathrm{ml}$ respectively. The median value of the $\mathrm{VL}$ of the patients included was $5.49 \log _{10}$ copies of $\mathrm{RNA} / \mathrm{ml}$; the minimum and maximum values were respectively 4.25 and $7.15 \log _{10}$ copies of RNA/ml.

Conclusion: The immunological and virological profile of HIV positive patients aged over 50 year in Kinshasa is not significantly different from the profiles of the general heterogeneous populations.

Keywords: Immunologic and Virological Profile; HIV; Over 50 years; Kinshasa

\section{Introduction}

After more than 30 years, the Human Immunodeficiency Virus (HIV) is still a public health problem around the world; and the Democratic Republic of Congo (DRC) is no exception. In 2014, the Demographic Health Survey (DHS) reported that the prevalence of HIV infection was $1.2 \%$ for a population aged between 15 to 49 years for the country and $1.6 \%$ for Kinshasa in the same age interval [1].

Although the National Program for the Control of HIV/AIDS and Sexually Transmitted Infections (PNLS) has adopted the "Test and Treat" option [2], virological, immunological and clinical parameters are always important for the decision of the correct treatment and proper care. The evaluation of these parameters is even more important for the management of sensitive populations such as children and the elderly. In the DRC in general, and in Kinshasa in particular, few data on clinical and paraclinical parameters are published on HIV-infected older adult patients.

Hence, the aim of this work was to evaluate the immunological and virological profile of HIV-infected patients over 50 years of age starting Antiretroviral Therapy (ART) in Kinshasa.

\section{Methods}

Twenty-seven (27) patients over the age of 50 years diagnosed positive for HIV Type 1 by serology in 3 Outpatient Treatment Centers (OTC) in Kinshasa during the period from 08 November 2013 to 14 February 2014 participated voluntarily in this work. All patients included in this work were naive to Antiretroviral Treatment (ART). 
Table 1: Characteristics of older patients infected by HIV starting treatment.

\begin{tabular}{|c|c|c|c|}
\hline Characteristics & \multicolumn{3}{|c|}{ Patients } \\
\hline \multicolumn{4}{|l|}{ Sex } \\
\hline Men & \multicolumn{3}{|c|}{$13(48.15 \%)$} \\
\hline Women & \multicolumn{3}{|c|}{$14(51.85 \%)$} \\
\hline Clinical Stage & Men & Women & Total \\
\hline Stage 2 & 2 & 2 & $4(14.8 \%)$ \\
\hline Stage 3 & 10 & 10 & $20(74.1 \%)$ \\
\hline Stage 4 & 1 & 2 & $3(11.1 \%)$ \\
\hline \multicolumn{4}{|l|}{ Biological Parameters } \\
\hline Median CD4 (cells/ml) & 153.8 & 241.2 & 227.78 \\
\hline Median Viral Load $\left(\log _{10}\right.$ ARN copies/ml) & 5.60 & 5.34 & 5.49 \\
\hline
\end{tabular}

After signing informed consent from the patients, blood samples were collected in $5 \mathrm{ml}$ tubes with anticoagulant EDTA. The immunological and virological profiles were evaluated respectively by the numbering of CD4+ and Viral Load (VL). These tests were performed for each patient at the inclusion (D0) in the Laboratory of Molecular Biology of the Faculty of Medicine of the University of Kinshasa. The clinical and paraclinical parameters were recorded on the patient files previously designed for the work.

\section{Results}

Of the 27 patients included in this work, 14(51.85\%) were women giving a sex ratio of $1: 1$. The median age of the general population was 58 years in the range of 50 to 70 years. Four patients $(14.8 \%)$ were in clinical stage 2 while $20(74.1 \%)$ in stage 3 and 3(11.1\%) in stage 4 according to the classification recommended by the World Health Organization (WHO). The median CD4 count at the inclusion was of 227.78 cells $/ \mathrm{ml}$. The minimum and maximum values of CD4 count were respectively 9 and 609 cells $/ \mathrm{ml}$. The median VL value of the included patients was of $5.49 \log _{10}$ RNA copies/ml (305 504 RNA copies $/ \mathrm{ml}$ ). The minimum and maximum values of VL were respectively 1.93 and $7.65 \log _{10}$ RNA copies $/ \mathrm{ml}$.

\section{Discussion}

The objective of this work was to evaluate the immunological and virological profile of HIV-infected patients over 50 years of age starting Antiretroviral Therapy (ART) in Kinshasa. Twenty-seven (27) HIVinfected and ART-naive older patients were included in this study, 14 patients $(51.85 \%)$ were women giving a sex ratio of $1: 1$. The median age of the population in general was 58 years in the range of 50 to 70 years. The dispersion of the 27 patients in the interval of 50 to 70 years was not Gaussian.

Four patients $(14.8 \%)$ were in clinical stage 2 while $20(74.1 \%)$ were in stage 3 and $3(11.1 \%)$ in stage 4 according to the WHO classification recommendations. This tendency to begin treatment in advanced stages of infection has been documented in our community by various studies [3]. Patients, usually in our midst, are screened for HIV infection when more or less severe symptoms develop; symptoms generally classifying in stage 3 of infection according to WHO's recommendations. This justifies the generally late diagnosis of HIV infected patients and the poor prognosis of treatment in our environment.

The median CD4 count was of 227.78 cells $/ \mathrm{ml}$. The minimum and maximum CD4 values we are respectively 9 and 609 cells/ml. Unlike the younger population (18 to 49 years), which tends to start treatment with a median CD4 value of less than 200 cells/ml [3,4]. Different studies in our environment have shown populations that started treatment with low median CD4+ levels generally less than 250 cells/ml [3-5]. This threshold, 200 to $250 \mathrm{cells} / \mathrm{ml}$, is considered as a poor prognosis for a successful treatment [6]. According to the recommendations of various experts, the threshold of 200 cells/ml after 6 months of ART is an indicator of treatment failure [7]. Although the differences are not statistically different between different populations, older patients over the age of 50 years were at higher risk for poor prognosis for HIV infection due to different age-related affections.

The median value of Viral Loads (VL) of the included patients was of $5.49 \log _{10}$ RNA copies/ml (305 504 RNA copies/ml). The minimum and maximum VL values were respectively 1.93 and $7.65 \log _{10}$ RNA copies $/ \mathrm{ml}$. The high VLs at the beginning of treatment are documented in our environment in different populations [3-5]. Elevated VLs in early ART are also signs of poor prognosis for treatment success $[6,7]$. This justifies the high rates of treatment failure of first intension in our environment [8]. The median VL value of general younger population of patients in previous study was about the same with the older patients (Table1).

\section{Limit of the study}

Due to different constraints, the time of inclusion of patients was limited in time. However, this does not remove the pertinence of the results.

\section{Conclusion}

The immunological and virological profile of HIV positive older adult patients in Kinshasa is not significantly different from the profiles of the general heterogeneous populations. Nevertheless, this population is a population at risk for age-related conditions associated with HIV.

\section{References}

1. Ministère du Plan et Suivi de la mise en œuvre de la révolution de la modernité, Ministère de Santé Publique (2014) Enquête Démographique et de Santé 2013-2014. République Démocratique du Congo (RDC), USA.

2. République Démocratique du Congo (RDC), Ministère de Santé (2017) Guide de Prise en Charge Intégrée du VIH en République Démocratique du Congo. Programme National de Lutte contre le SIDA et les IST (PNLS).

3. Kamangu NE, Bulanda IB, Bongenia IB, Botomwito TH, Mvumbi LG, et al. (2015) Virological Profile of Patients Infected with HIV Starting Antiretroviral Treatment in Kinshasa. Open Access Library Journal 2: 1-5. 
4. Kamangu NE, Bulanda BI, Bongenia Bl, Botomwito HT, Mvumbi GL, et al. (2016) Profil Virologique des patients infectés par le VIH en début de traitement antirétroviral à Kinshasa. Annales Africaines de Médecine 10.

5. Bulanda $\mathrm{BI}$, Kateba $\mathrm{ET}$, Bongenia $\mathrm{BI}$, Kasongo VN, Kingombe MA, et al. (2018) Sociodemographic and Anthropometric Profile of Positive HIV Patients in Early Traditional Treatment: Case of the Bonkoko Center. Open Access Library Journal 5: 1-8.

6. Egger M, May M, Chêne G, Phillips AN, Ledergerber B, et al. (2002) Prognosis of HIV-1-Infected Patients Starting Highly Active Therapy: A collaborative Analysis of Prospective Studies. The Lancet 360: 119129.

7. Morlat $P$ (2013) Prise en charge médicale des personnes vivant avec le VIH: Recommandations du groupe d'experts. Sous l'égide du CNS et de l'ANRS.

8. Kamangu NE (2018) Estimation of Clinical, Immunological and Virological Failure of First Line Antiretroviral Treatment in Kinshasa, Democratic Republic of Congo. Open Access Library Journal 5: 1-8. 